\title{
VARIATION IN LIQUID WASTE COMPOSITION SUPPLYING SELECTED COLLECTION POINT
}

\author{
Elżbieta Halina Grygorczuk-Petersons ${ }^{1}$, Józefa Wiater ${ }^{1}$
}

1 Department of Technology in Engineering and Environmental Protection, Bialystok University of Technology, Wiejska 45, 15-351 Bialystok, Poland, e-mail: e.petersons@pb.edu.pl; j.wiater@pb.edu.pl

Received: 2014.08.28

Accepted: 2014.10.17

Published: 2015.01.02

\begin{abstract}
The problem of liquid wastes is still current not only in Poland, but also in the world. The primary source of liquid wastes are single-family and multi-family houses. To a lesser extent, public service or production facilities, mainly in urban areas, are equipped with no-outlet reservoirs. Low concentrations in liquid wastes and their high density are often some difficulty to work with not only by sewage treatment plants, but also collection points. Therefore, the knowledge of the composition of liquid wastes supplied to the collection points is important. The paper presents the results of research as well as variability of concentrations of selected parameters of liquid wastes supplied to the collection point in Bialystok, that accepts both municipal and industrial sewage. Statistical processing of the obtained results and those derived from The Waterworks Bialystok showed the presence of high variability of total suspended matter and electrolytic conductivity as well as organic impurities expressed as $\mathrm{BOD}_{5}$ and $\mathrm{COD}$.
\end{abstract}

Keywords: collection points, liquid wastes, composition variability, permissible value

\section{INTRODUCTION}

Even at the present time, there is a specific solution of the sewage system in the cities, i.e. the no-outflow sewage system also called the "no-network system". In most cases, it serves as a temporary solution to the sewage system, at a time when investments are ahead of the construction of the sewerage system or if there is no economic justification for its construction [Kisiel, Bień 2005; Błażejewski, Nawrot 2009]. One of the elements of such system is collection points. The obligation of their construction, maintenance, and operation (individual or shared with other municipalities) is governed by the act requiring municipalities to maintain cleanliness and order in their locations [Act 1996]. Preferably, the collection point should be located at a smallest distance from the accumulation of liquid wastes, and the best solution is considered to locate it in the sewage treatment plant. The advantage of the collection point located in the sewage system at a distance from sewage treatment plant is that introduced impurities are mixed with sewage with- in the network, thus they are diluted and homogenized [Tomczuk 2011b].

Liquid wastes transported to the collection point are mixtures of various organic and inorganic matter dispersed in water, occurring in all states of matter. The degree of fragmentation of substances contained is very uneven. These may be large solid particles, fine particles of suspended solids, and emulsified colloidal and dissolved substances. The $\mathrm{pH}$ of the liquid waste can be very different: from the acid through neutral to alkaline, depending on their chemical composition [Maksymowicz, Opęchowski 2006].

Concentrations of selected parameters of liquid wastes, municipal and municipal-like ones, are usually far above the concentration in the wastewater influent through the sewage network, because spontaneously occurring biological processes leading to the degradation of organic matter and, consequently, to deposition of portion of solids at the bottom of the reservoir, in which they are temporarily stored [Grygorczuk-Petersons, Tałałaj 2007]. This portion of impurities, in respect of their composition, is similar to bottom 
sediments of a very high hydration degree [Bartoszewski et al. 2011].

Liquid wastes with large loads of biodegradable organic compounds emit odor of hydrogen sulfide, have black-gray color, and after filtration, are much less transparent than «fresh» wastewaters [Maksymowicz, Opęchowski 2006].

At the same time, in such wastes under the influence of anaerobic processes occurring in nooutflow reservoirs (rotting processes), an increasing in the concentration of selected parameters occurs. From sanitary point of view, this kind of wastes is very dangerous, because they contain large amounts of rotting or fermenting organic substances, pathogenic bacteria and viruses, as well as all types of human and animal-origin parasites.

Liquid wastes from service facilities, public buildings, or industry, may also contain infectious organisms, hazardous and toxic substances of organic and inorganic character.

It should be noted that liquid wastes accumulated in no-outflow reservoirs can be supplied to the collection point if this does not endanger the health of the station's service, construction, and proper operation of equipment, or the sewage treatment plant. For this reason, knowledge of the composition of liquid waste delivered to the collection point is extremely important.

Therefore, the work was undertaken, the purpose of which was to determine the variability of the physicochemical composition of liquid wastes supplied to the collection point in Bialystok, that accepts both municipal and industrial sewage, mainly from the food industry.

\section{MATERIALS AND METHODS}

\section{Characteristics of Liquid Wastes Collection point in Bialystok}

Liquid wastes generated in Bialystok and the surrounding areas, should go to The Liquid Wastes Collection point, that was taken over from the City Government of Bialystok in 1992 by Bialystok Waterworks Ltd. The Collection point was a well sized $3.20 \times 3.20 \mathrm{~m}$, to which the liquid wastes were poured directly from vacuum trucks. They were then mixed with municipal-farming sewage supplied by a collector with a diameter of $800 \mathrm{~mm}$, from part of the district Jaroszówka, Wyżyny estates, and the town Wasilkowo. As mixed wastes, they flew (also through a collector with a diameter of $800 \mathrm{~mm}$ ) to the wastewater treatment plant.
A new-generation container of the collection point with corresponding equipment (flow-meter Danfoss, device for sampling and measurement of wastewater $\mathrm{pH}$, computer with appropriate software) was installed in the collection point in March 2000.

In 2010-2013, the liquid wastes from average of 23 vacuum trucks were discharged into the collection point during a day. The average monthly amount of wastes supplied to the collection point was approximately $2500 \mathrm{~m}^{3}$ at the permitted quantity of $3500 \mathrm{~m}^{3} /$ month [Memo 2011].

The collection point accepts liquid wastes generated by households and industrial plants (dominated by the food industry), the provided documentation of the source of their origin and when they are not a threat to the safety and health of persons servicing the collection point and wastewater facilities. These wastes come mainly from Bialystok, but a small part of them is transported from nearby communities (Wasilków, Zaścianki, Juchnowiec Kościelny, Choroszcz, Sokółka, Turośń Kościelna, Dobrzyniewo Duże).

The amount of introduced liquid wastes is determined on the basis of indications of the measuring device owned by the Company.

Waterworks Bialystok lead the control of liquid wastes delivered to the collection point. This is done by control sampling during emptying the tank of the vacuum truck. Samples of liquid wastes from vacuum trucks are taken randomly. Sampling is done manually on the gravity pipeline. In case of exceeding the permitted contamination indices in liquid wastes as defined in Annex 2 and 3 to the agreement on the supplying of liquid wastes to the collection point [Contract 2011], the company pays an extra fee and bears the cost of the analyses. When the permissible limits of contaminants are not exceeded, the supplier bears only the cost of the liquid waste supplying to the collection point.

\section{Methods}

The study used the results of own research and those obtained from the Waterworks Bialystok. Samples of liquid wastes were collected from The Collection point in Bialystok in 2012. The samples were manually collected according to the norm [PN-ISO 5667-10: 1997] on the gravity pipeline located in the station area during emptying the vacuum trucks in the presence of the station's employee. 
Each time, 10 samples of liquid wastes from successively emptied vacuum trucks were collected, which were then transported to the laboratory of Technical University in Bialystok to determine selected indicators of contamination.

In order to reduce any errors in the research work, each sample was described by specifying the date, time, declared sources of liquid wastes and its address, the capacity of the vacuum truck, and the provider of liquid wastes.

The analyses included determining the following parameters performed in accordance with Polish norm: potentiometric $\mathrm{pH}$ with a $\mathrm{pH}-\mathrm{me}-$ ter Hach Session 4, electrolytic conductivity by means of conductivity method, total suspended solids by gravimetric method, organic substances measured by using the biochemical oxygen demand ( $\mathrm{BOD}_{5}$ by dilution method), and chemical oxygen demand by dichromate method $\left(\mathrm{COD}_{\mathrm{Cr}}\right)$. The results of the liquid wastes parameters were compared with acceptable indicators determined in the agreement on the introduction of liquid wastes into the collection point in Bialystok being in force in 2012 [Contract 2011].

The results obtained during the research $(80$ samples) are presented in tabular, graphical, and descriptive forms. Table 1 shows the statistics characterizing tested waste accumulation indicators calculated using STATISTICA v. 10.0 software: arithmetic mean, median, standard deviation, minimum, maximum, skewness (A).

In order to determine the compliance of the studied traits (determination results of pollution indicators) with normal distribution, the null hypothesis $\mathrm{H} 0$ was tested: the distribution of the test indicator is the normal distribution, against the alternative hypothesis $\mathrm{H} 1$ : the distribution is not a normal one. To verify the hypothesis, the $\chi 2$ test was applied, assuming the null hypothesis $\mathrm{H} 0$ at the significance level of $p>0.05$. Since the tested characteristics did not show any conformity with normal distribution, their compatibility with other types of distributions were analyzed, similarly as in the previous case.

Graphics shows "box with a mustache" type plots (Figure 1) and histograms (Figure 2) plotted using STATISTICA v.10.0 software, which show statistical differences between the tested parameters.

\section{RESULTS AND DISCUSSION}

The average value of electrolytic conductivity of liquid wastes delivered to the collection point (Table 1) was within the range of permissible limit values set by the Waterworks Bialystok and contained in the contract [Contract 2011] to their supply, while mean values of $\mathrm{BOD}_{5}$ and $\mathrm{COD}_{\mathrm{Cr}}$ as well as total suspended solids significantly exceeded those levels. The average $\mathrm{BOD}_{5}$ value determined for 2012 amounted to $2489 \mathrm{~g} / \mathrm{m}^{3}$ (Table 1), i.e. it exceeded the permissible level by almost 2.5-fold; the mean value of the suspension exceeded "the norm" more than 8 -fold and the average chemical oxygen demand 4.5 -fold.

Analyzing values of the minimum indicators of pollutants in liquid wastes, it should be noted that in all cases they reached values below the limit (Table 1), while the maximum values exceeded them many times as similar as average values. The maximum electrolytic conductivity was $24.6 \mathrm{mS} / \mathrm{cm}, \mathrm{BOD}_{5}-25000 \mathrm{~g} \mathrm{O}_{2} / \mathrm{m}^{3}$, maximum $\mathrm{COD}_{\mathrm{Cr}}$ up to $803306 \mathrm{~g} \mathrm{O}_{2} / \mathrm{m}^{3}$ (141 times higher than acceptable limit), and the maximum content of total suspended solids $90896 \mathrm{~g} / \mathrm{m}^{3}$ (61 times higher than permissible level).

Such a large excess, in particular in the case of suspensions, is evidence that the septic tanks may be leaking hence liquid infiltration into the ground occurs, which results in concentrating the liquid wastes. The second reason may be to provide to the collection point highly concentrated, industrial liquid wastes and leachates from the

Table 1. Statistics characterizing supplied liquid wastes

\begin{tabular}{|l|c|c|c|c|}
\hline \multicolumn{1}{|c|}{ Parameters } & $\begin{array}{c}\text { Reaction } \\
\mathrm{pH}\end{array}$ & $\begin{array}{c}\text { Electrolytic } \\
\text { conductivity } \\
{[\mathrm{mS} / \mathrm{cm}]}\end{array}$ & $\begin{array}{c}\mathrm{BOD}_{5} \\
{\left[\mathrm{~g} \mathrm{O}_{2} / \mathrm{m}^{3}\right]}\end{array}$ & $\begin{array}{c}\text { Total suspended } \\
\text { solids } \\
{\left[\mathrm{g} \mathrm{O} / \mathrm{m}^{3}\right]}\end{array}$ \\
\hline Threshold value [Contract 2011] & $6.5-9.5$ & $0.2-18$ & 1000 & 5700 \\
\hline Mean & - & 6.80 & 2489 & 28850 \\
\hline Minimum & 2.3 & 0.1 & 100 & 503 \\
\hline Maximum & 11.6 & 24.6 & 25000 & 803306 \\
\hline Median & 7.4 & 3.75 & 1500 & 4090 \\
\hline Standard deviation & - & 6.33 & 3691 & 125540 \\
\hline Skewness (A) & -1.04 & 1.26 & 4.61 & 245 \\
\hline
\end{tabular}



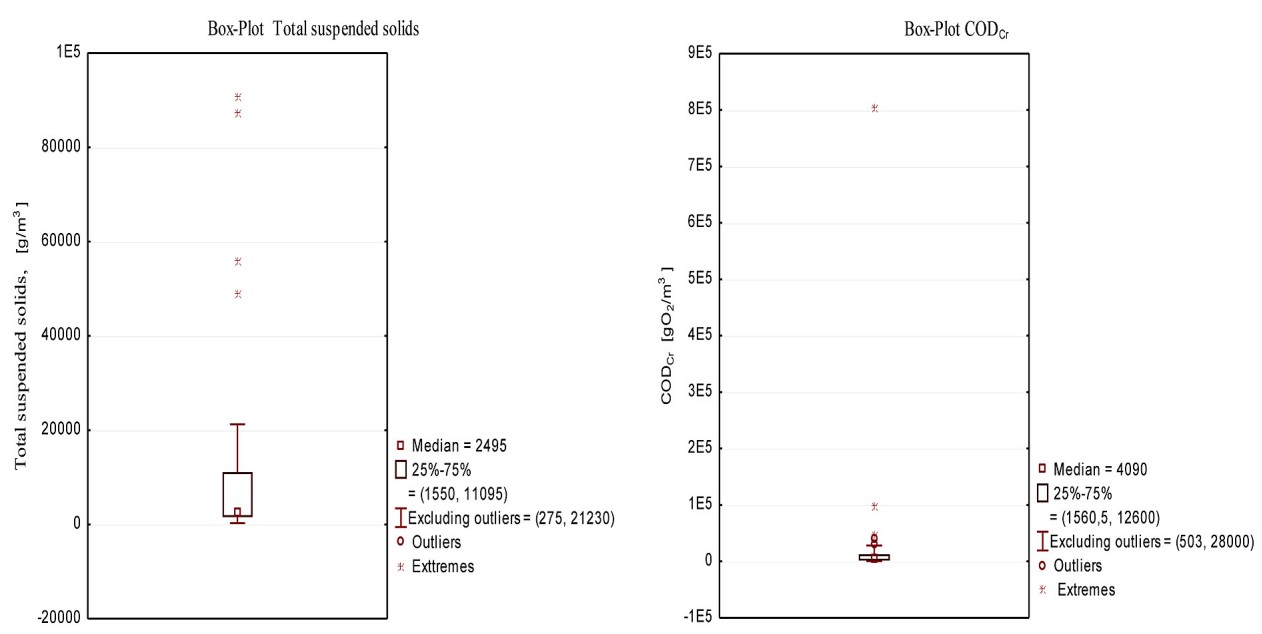

Figure 1. Range of oscillations of total suspended solids and $\mathrm{COD}_{\mathrm{Cr}}$ in liquid wastes

Waste Treatment Plant in Hryniewicze characterized by, among others, high electrolytic conductivity value and high levels of pollutants expressed as COD [Leszczyński 2011 and 2013].

Statistical processing of results (Table 1) showed the existence of large disparities between pollutant concentrations expressed as the contents of $\mathrm{BOD}_{5}$ and $\mathrm{COD}_{\mathrm{Cr}}$, total suspended solids, and electrolytic conductivity, due to the very large difference between the median values and mean values of the analyzed parameters.

Based on the minimum and maximum values (Table 1, Figure 1), very large differences between obtained values of the individual parameters of liquid wastes were recorded. Standard deviations show their considerable dispersion. Also, graphs of "boxes with a mustache" type exhibit large fluctuations in the analyzed indicators of impurities in the liquid wastes supplied to the collection point (Figure 1).

It was found that span values of the analyzed parameters were remarkable. In all cases, the occurrence of outliers and extreme for $\mathrm{pH}$, electrolytic conductivity, $\mathrm{BOD}_{5}, \mathrm{COD}_{\mathrm{Cr}}$ and total suspended solids, was observed (Figure 1).

It was found that the resulting properties (results of pollution indices determination) in the liquid wastes were not to conform with the normal distribution, therefore, the compatibility of the distribution of analyzed features with other distributions were verified. Following distributions were taken into account: exponential, gamma, lognormal, and $\chi 2$. The assessment of the compliance with those distributions was carried out on the basis of the $\chi 2$ test.

The hypothesis on the compliance with the exponential distribution was assumed for $\mathrm{BOD}_{5}$
(Figure 2c). Other characteristics ( $\mathrm{pH}$, conductivity, COD, and suspended solids), due to the low probability of the test (less than 0.05 ) showed no statistically significant compliance with any of the analyzed distribution.

On the basis of the presented histograms, it can be also specified a range of the most frequently achieved results and the significant range of the indicator occurrence (Figure 2). Therefore, it was concluded that liquid wastes were characterized by:

- in $79.1 \% \mathrm{pH}$ from the range of 6-8 $\mathrm{pH}$ (Figure $2 a)$,

- in $68.3 \% \mathrm{COD}_{\mathrm{Cr}}$ from the range of $503-$ $10000 \mathrm{gO}_{2} / \mathrm{m}^{3}$,

- in $61 \%$ electrolytic conductivity from the range of $0.1-6 \mathrm{mS} / \mathrm{cm}$, including in $36.6 \%$ values from 2 to $4 \mathrm{mS} / \mathrm{cm}$ (Figure 2b);

- in $86.6 \% \mathrm{BOD}_{5}$ from the range of $100-4000$ $\mathrm{g} \mathrm{O}_{2} / \mathrm{m}^{3}$, including in $54.6 \%$ values from 100 to $2000 \mathrm{~g} \mathrm{O}_{2} / \mathrm{m}^{3}$ (Figure 2c),

- in $72.9 \%$ total suspended solids from the range of $275-20000 \mathrm{~g} / \mathrm{m}^{3}$ (Figure 2d).

In the case of electrical conductivity, total suspended solids, $\mathrm{BOD}_{5}$, and $\mathrm{COD}_{(\mathrm{Cr})}$ histograms, the existence of a strong the right-hand asymmetry of the distribution was showed, which means that for these indicators of pollution, there are individual high and very high values (Figure 2, Table 1), while the vast majority of results ranged below the average. Only in the case of $\mathrm{pH}$, a strong left-hand asymmetry $(\mathrm{A}=-1.04)$ was observed indicating that most of the analyzed samples of liquid wastes had a $\mathrm{pH}$ above average (Table 1, Figure 2a).

A comparison of indicators of liquid waste delivered and municipal wastewater shown that the minimum values of parameters of liquid wastes 

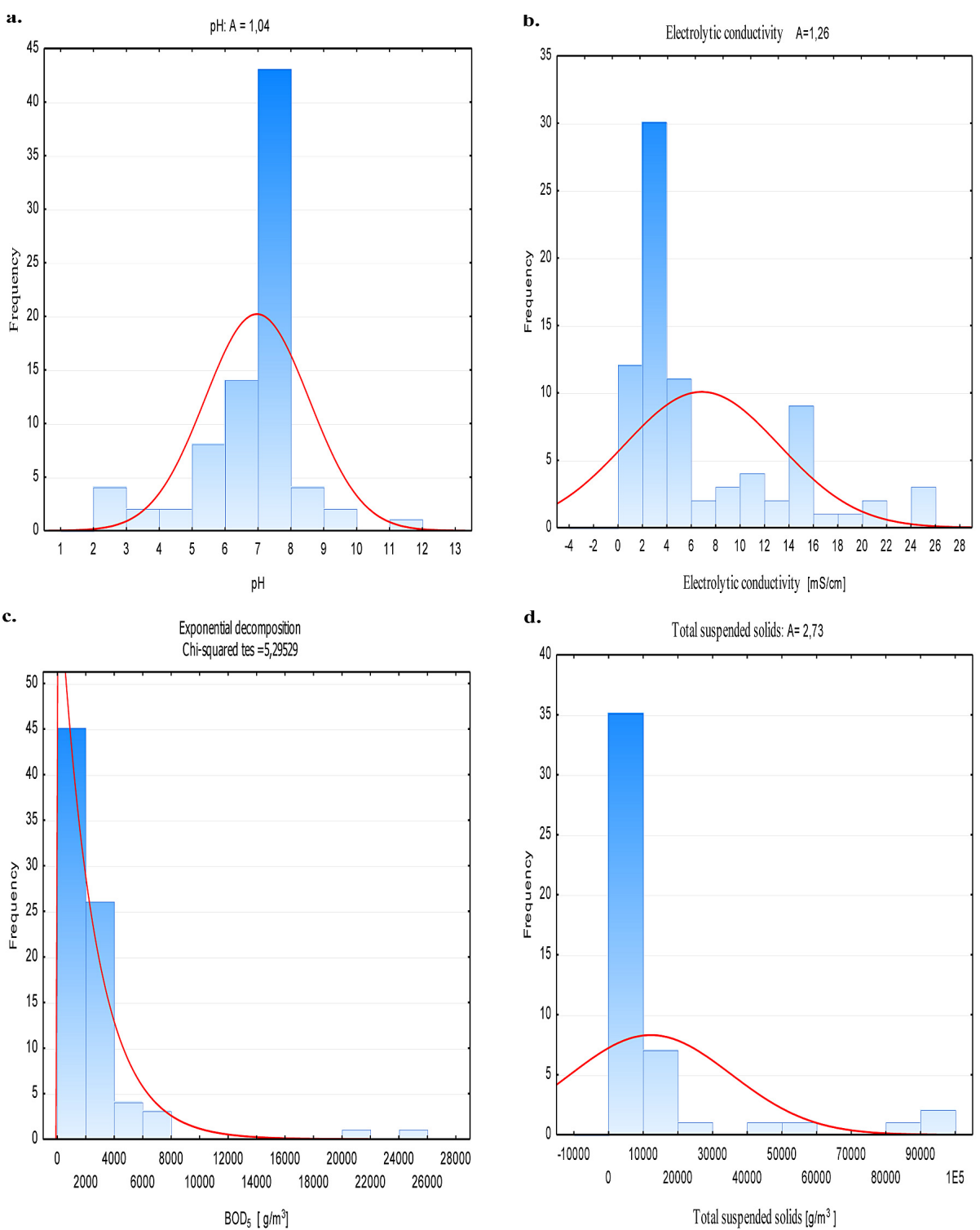

Figure 2. Histograms of selected parameters

supplied to the collection point in Bialystok had much smaller values than the municipal sewage quoted by various authors: Maksymowicz and Opęchowski [2001] as well as Simpson [2008] (Table 2). At the same time, the maximum values exceeded them repeatedly. For example, according to own research, $\mathrm{BOD}_{5}$ for liquid wastes accepted a value from 100 to $25000 \mathrm{~g} \mathrm{O}_{2} / \mathrm{m}^{3}$, while $\mathrm{BOD}_{5}$ for municipal wastewater according to research by Maksymowicz and Opęchowski from 150 to $500 \mathrm{~g} \mathrm{O}_{2} / \mathrm{m}^{3}$, and the research by Simson - from 346 to $527 \mathrm{~g} \mathrm{O}_{2} / \mathrm{m}^{3}$ (Table 2).

The analysis of liquid waste pollution indicators showed the existence of large span between values of the analyzed parameters (Table 2). The variation range of selected parameters was higher than that in the studies by Maksymowicz and Opęchowski [2001] (Table 2), and the mean val- ues several times higher than values obtained by Tomczuk [2011a] (Table 1 and 2).

Largely dispersed values of the analyzed contamination indicators of liquid wastes delivered to the collection point in Bialystok confirm, among others, the diversity of liquid waste sources (single-family and multi-family residences, waste treatment plant in Hryniewicze, service facilities, industrial plants), no sealing of some no-outflow reservoirs, and low frequency of their transport.

\section{CONCLUSIONS}

1. Liquid wastes delivered to the collection point in Bialystok in 2012 were characterized by a high variability of composition. This resulted mainly from the diversity of the liquid waste 
Table 2. Characteristics of sewage and liquid wastes

\begin{tabular}{|l|c|c|c|c|c|}
\hline \multirow{2}{*}{ Index } & \multicolumn{4}{|c|}{ Volues } \\
\cline { 2 - 6 } & \multicolumn{2}{|c|}{ Municipal sewage } & \multicolumn{3}{c|}{ Liquid wastes } \\
\cline { 2 - 6 } & $\begin{array}{c}\text { Simson } \\
2008\end{array}$ & $\begin{array}{c}\text { Maksymowicz. } \\
\text { Opęchowski 2001 }\end{array}$ & $\begin{array}{c}\text { Maksymowicz. } \\
\text { Opęchowski 2001 }\end{array}$ & $\begin{array}{c}\text { Tomczuk 2011a } \\
\text { (mean) }\end{array}$ & $\begin{array}{c}\text { Own and } \\
\text { Waterworks }\end{array}$ \\
\hline $\begin{array}{l}\text { Total suspended solids } \\
{\left[\mathrm{g} / \mathrm{m}^{3}\right]}\end{array}$ & $417-676$ & $1200-3200$ & $2500-50000$ & 116 & $275-90896$ \\
\hline $\begin{array}{l}\mathrm{BOD}_{5} \\
{\left[\mathrm{gO}_{2} / \mathrm{m}^{3}\right]}\end{array}$ & $346-527$ & $150-500$ & $1000-7000$ & 1080 & $100-25000$ \\
\hline $\begin{array}{l}\mathrm{COD}_{\mathrm{cr}} \\
{\left[\mathrm{gO}_{2} / \mathrm{m}^{3}\right]}\end{array}$ & $796-1239$ & $250-1000$ & $2500-15000$ & 1790 & $503-803306$ \\
\hline $\begin{array}{l}\mathrm{Electrolytic} \mathrm{conductivity} \\
{[\mathrm{mS} / \mathrm{cm}]}\end{array}$ & - & - & - & 2.9 & $0.1-24.6$ \\
\hline Reaction pH & $6.8-7.9$ & - & - & 7.7 & $2.3-11.6$ \\
\hline
\end{tabular}

types originating both from municipal housing, and public facilities, service establishments, or industry.

2. The values of the limit parameters set by the Waterworks Bialystok, which are indicated in the agreements between the collection point administrator and waste suppliers are notoriously exceeded.

3. The results of the study consist of determined, real parameters of liquid wastes delivered to the collection point in Bialystok, which demonstrate the need for their more frequent checks. Such tests are performed too rarely, which means that Suppliers of the wastes in a situation of exceeded permissible levels specified in the contract [Contract 2011] do not bear the actual costs associated with the introduction of impurities determined by the exceeding levels of pollutants contained therein.

\section{REFERENCES}

1. Bartoszewski K. at al. 2011. Poradnik eksploatatora oczyszczalni ścieków. Wyd. PZIiTS, Oddz. Wlkp. Poznań. [In Polish].

2. Błażejewski R., Nawrot T. 2009. Jak uszczelnić system gromadzenia i dowożenia nieczystości ciekłych?. GWiTS, 9. [In Polish].

3. Grygorczuk-Petersons E., Tałałaj I. 2007. Kształtowanie gospodarki odpadami w gminie. Podlaska Agencja Zarządzania Energią. Białystok. [In Polish].

4. Heidrich Z. 2005. Gospodarka wodno-ściekowa. Centrum Informacyjne Lasów Państwowych. [In Polish].

5. Kisiel J., Bień J. 2005. Wspołdzialanie retencyjnego zbiornika stacji zlewnej $\mathrm{z}$ oczyszczalnią ścieków. [In:] Zintegrowane, inteligentne systemy wykorzystywania energii odnawialnej. Mat. Konf. Częstochowa-Podlesice. [In Polish].
6. Leszczyński J. 2011. Podczyszczanie odcieków ze składowiska odpadów stałych metodą koagulacji. Inżynieria Ekologiczna, 25, 242-250. [In Polish].

7. Leszczyński J. 2013. Zastosowanie procesu Fentona do podczyszczania odcieków składowiskowych. Instal, 6(341), 52-54. [In Polish].

8. Maksymowicz B., Opęchowski S. 2006. Zasady gospodarowania nieczystościami ciekłymi. Poradnik. Łódź. [In Polish].

9. Maksymowicz B., Opęchowski S. 2001. Zasady sporządzania przez gminy programów postępowania $\mathrm{z}$ nieczystościami ciekłymi $\mathrm{z}$ terenów nieskanalizowanych z uwzględnieniem dyrektyw Unii Europejskiej. Poradnik praktyczny dla gmin. OBREM, Łódź. [In Polish].

10. Memo 2011. Notatka służbowa Wodociągów Białostockich Sp. z.o.o.. Białystok. Unpublished typescript. [In Polish].

11. PN-ISO 5667-10: 1997. Jakość wody. Pobranie próbek. Wytyczne pobierania próbek ścieków. [In Polish].

12. Simson G. 2008. Pierwsze doświadczenia test technologiczny $\mathrm{z}$ zastosowaniem preparatu BRENNTAPLUS VP1, jako zewnętrzne źródło węgla organicznego do intensyfikacji procesu denitryfikacji w Białostockiej Oczyszczalni. Forum Ekspoatatora, 6, 21-23. [In Polish].

13. Tomczuk B. 2011a. Ścieki dowożone czy nieczystości ciekłe? Forum Eksploatatora, 2(53), 82-83. [In Polish].

14. Tomczuk B. 2011b. Stacje zlewne nieczystości ciekłych - przegląd dostępnych rozwiązań. Forum Eksploatatora, 3(54), 70-71. [In Polish].

15. Contract 2011. Umowa o wprowadzanie nieczystości ciekłych do stacji zlewnej. 2011. Białystok. Maszyn. niepubl [In Polish].

16. Act 1996: Ustawa z dnia 13 września 1996 r. o utrzymaniu czystości i porządku w gminach (tekst jednolity z 2012 r. Dz.U. 2011 poz. 391 z poźn. zm.). [In Polish]. 